\title{
A MODEL FOR CURRICULUM DEVELOPMENT IN NURSING
}

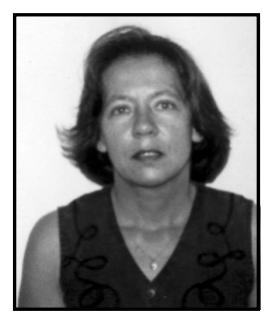

\author{
Louise De Villiers \\ D. Litt et Phil. (Unisa) \\ Lecturer, Department of Advanced Nursing Sciences \\ University of South Africa
}

\section{Key terms}

Curriculum; Curriculum development.

\section{SUMMARY}

A curriculum model for curriculum development in nursing and the health sciences is discussed. This model establishes a strategy by which curriculum development can be approached comprehensively and systematically. The steps and tasks inherent in the three curriculum development phases, namely planning, design and application are outlined. Application of the Model for Curriculum Development in Nursing would lead to the establishment of a curriculum document that comprises sections on the foundations of the proposed curriculum, an educational plan and an implementation strategy.

\section{OPSOMMING}

'n Model vir kurrikulumontwikkeling in Verpleegkunde en die gesondheidswetenskappe word bespreek. Die model stel 'n strategie daar waarvolgens kurrikulumontwikkeling omvattend en sistematies benader kan word. Die stappe en take verbonde aan elk van die drie fases van kurrikulumontwikkeling, naamlik beplanning, ontwerp en toepassing, word bespreek. Toepassing van die Model vir Kurrikulumontwikkeling in Verpleegkunde behoort te lei na die daarstelling van 'n kurrikulumdokument bestaande uit afdelings wat handel oor die grondslag van die voorgestelde kurrikulum, 'n opvoedkundige plan, asook 'n strategie vir die implementering van die opvoedkundige plan.

\section{INTRODUCTION}

This article is based upon literature research aimed at theorising about a curriculum development model for the Programme Leading to Registration as a Nurse (General, Psychiatric and Community) and Midwife (South African Nursing Council, 1985). One of the outcomes of this research is a curriculum development model that establishes a strategy by which curriculum development can be approached comprehensively and systematically (De Villiers, 1998:168-203). The purpose of this article is to discuss the Model for Curriculum Development in Nursing.

\section{CURRICULUM DEVELOPMENT MODEL}

Print (1993:23) defines curriculum development as, “...the process of planning, implementing and evaluating learning opportunities intended to produce desired changes in learners". A model is a representation of the interactions among and between concepts that shows the patterns of these interactions (George, 1995:387). A curriculum development model is used to study the components of a curriculum and the relationships between these components (Print, 1993:61-62).

Within the context of the study, a curriculum 
development model is a symbolic representation of the relationships between specified curriculum development phases, steps and tasks that constitute a curriculum development process.

\section{THE NATURE OF A CURRICULUM}

Curriculum refers to running; a course; racechariot and is derived from the Latin word currere which means to run (Billings \& Halstead, 1998:7071; Brown, 1993:574). Within the educational context, curriculum refers to a course of study at a school, university; the subjects making up a course; an educational journey that the learner embarks upon (Brown, 1993:574; Lovat \& Smith, 1995:89; 18-19).

Although much has been written about what a curriculum is, it is important to acknowledge the model of Zais (1976:96-98) in which the nature of a curriculum is clearly conceptualised in terms of its foundations and its structure. The foundations of a curriculum are the philosophical bases thereof. The philosophical bases of a curriculum refer to the underlying values and beliefs that influence the curriculum structure and its substance. Any decision that educators make about a curriculum is influenced by their philosophical assumptions about the epistemology (the nature of knowledge), society/culture, the individual (specifically the learner) and learning (how a person learns and what learning theories the curriculum should be based upon). Curriculum structure refers to the various components of a curriculum. These components are aims/goals/objectives, content, learning activities and evaluation.

Considering Zais' model, the author adopted the stance that curriculum development should involve decision making about the foundations and structure of a curriculum.

A limitation of Zais' model lies in its failure to acknowledge the contextual nature of a curriculum.
Lawton (1983:24-39) developed a cultural analysis model that is based upon the assumption that the main purpose of a curriculum is to initiate learners into the cultural heritage of society. Curriculum development involves making appropriate selections from culture. To facilitate such selections, it is imperative to understand the social contexts of a particular curriculum. Such understandings are pursued by means of the technique of cultural analysis.

It is clear from the above that a situational analysis is an essential curriculum development activity.

\section{CURRICULUM DEVELOPMENT MODELS THAT TRADITIONALLY INFLUENCE NURSING EDUCATION}

In the past, curriculum development in nursing has been influenced by various classical curriculum development models that reflect different curriculum development paradigms. These models contributed towards progress in nursing education.

\section{Linear, prescriptive curriculum development models}

Linear, prescriptive curriculum development models are normative models because they provide a sequence of steps that writers say, should be used in any curriculum development initiative (Lovat \& Smith, 1995:106).

Tyler's curriculum development model is an example of linear, prescriptive curriculum development models. This model represents a technical, objectives driven approach whereby educators specify the desired product of an educational programme and use this as a point of departure for curriculum development (Lovat \& Smith, 1995:107).

Tyler's model states the involvement of three curriculum components in curriculum development, 
namely goals, content and evaluation, as well as curriculum design. According to Tyler's model curriculum development proceeds in a linear fashion. First objectives, namely the behaviour that a learner should be able to display through his/her thoughts, actions or feelings are formulated, usually in behavioural terms. These objectives are organised according to a hierarchy that allows learners to proceed in a step-by step manner through lower level to higher levels of behaviour. Then relevant curriculum content is selected and organised to ensure that the stated objectives are met in a logical fashion. Tyler's model is called prescriptive because the stated hierarchy of objectives is a predetermined educational plan, or blueprint, to be followed by educators and learners. Lastly, assessment criteria to measure achievement of the stated objectives are developed (Lovat \& Smith, 1995:107-108).

\section{Cyclic curriculum development models}

Cyclic curriculum development models depict curriculum development as a rational and orderly process (Lovat \& Smith, 1995:109). These models indicate that the curriculum development actions are interrelated and interactive. The model of Nicholls and Nicholls (1978) is an example of cyclic curriculum development models.

Nicholls and Nicholls (1978:21) specify the involvement of five curriculum components in their cyclic curriculum development model, namely the situational analysis, selection of objectives, selection and organisation of content, selection and organisation of methods and evaluation of learning. Nicholls and Nicholls' model differs from that of Tyler in that provision is made for the situational analysis, content is separated from learning experiences, and curriculum design is applied to the components of curriculum content and learning opportunities.

The cyclic curriculum development models have no particular starting point. Any of the curriculum components can serve as a stimulus for curriculum development. Upon completion of the curriculum development process, any curriculum component can stimulate a repeat of the process (Print, 1993:69-74). Lovat \& Smith (1995:109) purports that cyclic curriculum development models do not substantially differ from the linear models by saying, “... simply because an approach is provided in a cycle, ... that does not transform it from being linear and unidirectional: a circle is simply a line with the ends joined together." The cyclic curriculum development model differs from the linear model in that it is not objectives driven. A major limitation of the linear and cyclic curriculum development models is their failure to acknowledge the influence of the foundations of a curriculum on curriculum design and implementation. It is therefore necessary to consider another type of curriculum development model, namely dynamic curriculum development models.

\section{Dynamic curriculum development models}

Dynamic curriculum development models depict curriculum development as being a complex, dynamic, interactive and flexible process. The models of Walker (1971:52-59) and Print (1993:8189) are examples of dynamic curriculum development models.

Walker (Short \& Grove, 1994:6; Walker, 1971:5259; Walker \& Soltis, 1992:60-61) identifies three dimensions of curriculum development, namely platform, deliberations and design. Curriculum platform refers to the personal belief systems and visions of those who are involved with curriculum development. The curriculum platform influences decision-making about the proposed curriculum. Deliberations involve dialogue, debating and arguing about the curriculum platform. Those involved with curriculum development examine and defend their platform points of view. An acceptable perspective for a particular curriculum 
is chosen and curriculum design is then approached in accordance with the chosen perspective. Curriculum design is a set of abstract relationships between the curriculum components. It is the endresult of curriculum development.

Print's (1993:81-89) model depicts curriculum development as a process comprising three phases, namely organisation or presage, development and application. Organisation or presage is a conceptualisation and planning phase. Curriculum development is influenced by the personal perspectives and value systems of those who are involved in the process. This phase involves discussions on preconceived visions about the foundations of a curriculum and the purpose of education. Based on these discussions, criteria for the proposed curriculum are formulated (Print, 1993:25-57). Print (1993:46) maintains that a curriculum document should include statements about the perspectives that influenced its development. Curriculum development is the phase during which a workable curriculum is developed. A situational analysis is done and based on the findings, decisions are made about each of the curriculum components, namely goals, content, learning activities and evaluation of learning. These decisions are incorporated into a curriculum document. Curriculum application involves implementing the newly developed curriculum and modifying it to rectify problem areas, and curriculum evaluation (Print, 1993:81-88).

The linear-prescriptive and cyclic models do not allow explicitly for deliberations about the foundations of a curriculum. The dynamic curriculum development models bridge that gap because educators can participate, together with interested parties such as learners, community leaders and practitioners, in the deliberations about the curriculum platform, and the philosophical bases on which the proposed curriculum will be based. Print's model is unique in the sense that curriculum application is seen as part of the curriculum development process. Another feature of this model is that a clear distinction is made between assessment of learning and curriculum evaluation.

Curriculum development is therefore a process that comprises curriculum planning, design and application involving deliberations and decisionmaking about the foundations and structure of the proposed curriculum.

\section{CURRICULUM DEVELOPMENT: A PROBLEM AREA IN NURSING EDUCATION}

Appeals for curriculum changes are often voiced in the nursing literature. This can be effected by means of curriculum development. Curriculum development in nursing is complicated by current uncoordinated curriculum development initiatives promoted by individual organisations or groups, which are also characterised by a lack of a clear curriculum development strategy (Stucky, 1997:9).

Curriculum development ought to proceed according to a clear curriculum development strategy. Such a strategy could be established through a curriculum development model. A curriculum development model should guide nurse educators through the curriculum development process to ensure that curriculum development is conducted systematically and comprehensively.

With the above in mind, the author undertook research to design a model that could serve as a practical guideline for curriculum development in nursing to effect fundamental curriculum changes. The research process and the main findings that influenced the conceptualisation of the Model are discussed in a previous article (De Villiers, 1999:311).

The problem statement for the study was as follows: What kind of curriculum development model is 
suitable for nursing, which concepts should be included in such a model and what are the relationships between these concepts?

\section{THE MODEL FOR CURRICULUM DEVELOPMENT IN NURSING}

The Model for Curriculum Development in Nursing is a process model, which specifies the phases that are involved in curriculum development, as well as the steps that could be followed to complete specified curriculum development tasks.

\section{Underlying assumptions}

The Model for Curriculum Development in Nursing is based upon various assumptions about curriculum development, namely:

- Curriculum development must lead to fundamental curriculum changes.

- A comprehensive curriculum development approach requires decision-making about all the curriculum components that constitute the curriculum structure.

- Fundamental curriculum changes require that decision-making be based on insight into the fundamental issues influencing the nursing curriculum.

- A curriculum committee is primarily responsible for curriculum development.

- National, international and professional tendencies influence curriculum development.

- Curriculum development can be done in an accountable manner if guided by a relevant curriculum development model.

- A curriculum development model must be designed by means of scientific research.

\section{Context for the implementation of the model}

The Model for Curriculum Development in Nursing can be used as a guide for curriculum development for the Programme Leading to Registration as a Nurse (General, Psychiatric and Community) and
Midwife (South African Nursing Council, 1985). However, the curriculum development phases, steps and tasks are universal and the applicability of the Model is therefore not limited to that educational programme or the nursing profession.

\section{Constitutive concepts}

A model represents an entity's constitutive components and the relationships between those components. The components of an entity are conceived and defined by means of constitutive concepts. The relationships between the constitutive concepts are conceived and defined through structural concepts (Short \& Grove, 1994:3).

The constitutive concepts of the Model for Curriculum Development in Nursing (figure 1) are curriculum and curriculum development.

\section{Curriculum}

Curriculum is within the context of this model, an educational plan for achieving the aims of the Programme Leading to Registration as a Nurse (General, Psychiatric and Community) and Midwife in which the planned outcomes, curriculum content, learning opportunities and assessment standards are specified. It also includes an implementation strategy, namely guidelines for teaching-learning strategies, the role of the educator, the learning climate, and assessment strategies and criteria. The concept curriculum encompasses two sub-concepts, namely foundations and structure. A curriculum is socially situated. The social tendencies that influence the curriculum are determined by means of a situational analysis.

\section{Curriculum development}

Curriculum development is a systematic process that encompasses various phases namely planning, design and application. 
Figure 1: The model for curriculum development in nursing 


\section{Structural concepts}

The Model for Curriculum Development in Nursing displays relationships between curriculum development tasks that should be completed, as well as the phases and steps that would be followed to ensure that the stated tasks are approached systematically by the curriculum committee.

\section{CURRICULUM PLANNING}

Curriculum planning comprises a cycle of deliberations and verification aimed at compiling a draft curriculum framework. Various tasks are completed by following particular steps.

\section{Deliberations about the foundations of the proposed curriculum}

Curriculum planning commences with a debate, by the curriculum committee, about the foundations of the proposed curriculum. Personal perspectives and opinions are debated until consensus is reached about the perspective that will be adopted as a basis for the proposed curriculum.

\section{Formulating foundation propositions}

The consensus decisions about the nature of a curriculum are communicated in the form of a definition of curriculum. The curriculum that is subsequently being developed must be consistent with this definition. A definition of curriculum in terms of a collection of subjects supports the development of a content centred curriculum (Ornstein \& Levine, 1993:10, 243). A definition of curriculum as a set of planned outcomes supports the development of an outcome based curriculum (Ornstein \& Hunkins, 1998:10; Spady \& Marshall, 1991:67). A definition of curriculum as a set of planned learning experiences supports the development of a curriculum that consists of a set of learning experiences and the description of the ideal learning climate (Ornstein \& Hunkins, 1998:10). A definition that stipulates that a curriculum comprises a conceptual and a cultural dimension supports the development of a curriculum that consists of an educational plan, as well as an implementation strategy (Grundy, 1987:5, 7). This definition represents an eclectic approach that acknowledges the unity between curriculum planning and curriculum implementation (Lovat \& Smith, 1995:15).

Curriculum development is undertaken with a clear purpose in mind, that is, the curriculum committee anticipates the contributions of the proposed curriculum for the profession. An expression of the purpose of the nursing curriculum in terms of conveyance of the intellectual tradition or culture of nursing supports the development of a content centred or an outcome based curriculum (Klein, 1986:32; Print, 1993:47-49; Tanner \& Tanner, 1995:165; Vallance, 1986:24-25). The purpose of the nursing curriculum viewed in terms of the intellectual development of students paves the way for the development of a process and problem centred curriculum (Print, 1993:49-51; Tanner \& Tanner, 1995:167-170; Valance, 1986:24). The selfactualisation purpose supports the development of a learner centred, flexible curriculum (Lefrancois, 1997:112-113, 318, 324-325; Print, 1993:51-52; Vallance, 1986:25-26). An expression of the purpose of the nursing curriculum in terms of social reform supports the development of a praxis curriculum that is activity and life situation centred (Print, 1993:52-54; Vallance, 1986:24-25). The purpose of the nursing curriculum viewed in terms of personal commitment supports the development of a curriculum that will promote a personal commitment towards intellectual inquiry and learning. This commitment is associated with a passion for working hard and experiencing the joys of intellectual exploration. This purpose also incorporates the above purposes (Vallance, 1986:27-28).

The curriculum committee approaches curriculum development according to a particular philosophical 
orientation. Examples are realism, idealism, pragmatism and existentialism. A corresponding educational philosophy is chosen to guide curriculum development. Possible educational philosophies are perennialism, essentialism, progressivism and reconstructionism. Perennialism is based on realism and supports career oriented education (Billings \& Halstead, 1998:74; Ornstein \& Levine, 1993:460). Essentialism is grounded in idealism and pragmatism. The focus is on exposing students to the ideas and questions that experts have formulated to promote in-depth understandings and conceptual thinking abilities (Billings \& Halstead, 1998:74; Ornstein \& Levine, 1993:464). Progressivism is grounded in pragmatism. The educational aim is to develop scientific inquiry, critical thinking and problem solving skills, as well as the ability to adapt to constant social changes (Billings \& Halstead, 1998:74; Ornstein \& Hunkins, 1998:44-46, 56; McNeil, 1996:8-10; Ornstein \& Levine, 1993:48, 234, 237). Reconstructionism is based on a philosophy of society in crisis, as well as on pragmatism. The curriculum supports society centred education that contributes towards social reform (Billings \& Halstead, 1998:74; Ornstein \& Hunkins, 1998:50-51, 56).

Education, and therefore the curriculum, is essentially concerned with knowledge. Knowledge that we possess and our understandings about the world are shaped by ideology (Lovat \& Smith, 1995:11, 32, 74). Members of the curriculum committee engage in deliberations about epistemology to reach consensus about the nature of knowledge and the knowledge that students should acquire as a result of their interactions with the proposed curriculum. Viewed from the perspective of realism, knowledge is something that may be known, that can be verified through empirical research. The learner studies subject matter that is external and fixed, and describes what has been learnt objectively. The curriculum is content based and comprises the sciences and the arts, with emphasis on the natural sciences. Idealism views knowledge in terms of the meanings that the learner attaches to what is learnt, in the form of ideas. The subject disciplines are studied in order to develop conceptual thought processes that enable the learner to obtain a general perspective about the world. Preference is given to abstract subjects such as philosophy. According to pragmatism, the learner achieves knowledge through transactions with the environment and personal experiences that result in a process of knowledge construction. Knowledge is tentative because sustained experiences lead to new insights and the learner also contributes to social changes through reflective thinking and problem solving. Preference is given to knowledge that has practical applications. It includes processes such as research and problem solving. Existentialism values knowledge that contributes towards self-actualisation of the individual. Preference is given to literature, drama and art that lead to philosophical discourse and making of choices. This perspective acknowledges that the learner transforms objective knowledge about the external world into personal knowledge through a process of internalisation (Cobb in Gravett \& Henning, 1998:61; Billings \& Halstead, 1999:104-111). Knowing is closely related to knowledge and is often used to refer to showing knowledge or awareness (Brown, 1993:1503). The curriculum committee should specify the levels of knowing that would result from interactions with the proposed curriculum. The levels can be conceptualised in terms of Habermas' (Lovat \& Smith, 1995:92-94) ways of knowing, namely the empirical-analytical (knowing facts and being able to perform practical skills), interpretativehermeneutical (critical interpretation and meaningmaking) and self-reflective (critical engagement in practical action for change) ways of knowing. This influences curriculum design with regard to learning opportunities, allowing for the development of learners towards higher levels of cognitive functioning.

The proposed characteristics of a graduate able to 
meet the needs of society, are stipulated (Zais, 1976:162-167). These proposed characteristics serve as points of departure for the formulation of exit outcomes for a particular learning programme. An example is the ability to practise critical thinking and life-long learning, as well as the ability to render comprehensive health care independently and competently.

The cultural basis of the nursing curriculum and the ways in which cultural bias is minimised, should be stated. Statements about the preferred language (-s) of instruction could also be formulated. In light of the technological realities that students are faced with, the value of especially the electronic media should be acknowledged.

The curriculum committee's views about the nature of the individual and the ways in which he/she learns, influence their decision about the learning theory(-ies) on which the proposed curriculum would be based.

- The stimulus-response learning theories are congruent with the cultural conveyance curriculum purpose, as well as perrenialism and essentialism.

- The cognitive field learning theories are congruent with the intellectual development curriculum purpose and progressivism.

- The phenomenological-humanistic learning theories are congruent with the selfactualisation curriculum purpose and progressivism.

- The cognitive development learning theories are congruent with the social reform curriculum purpose, and reconstructionism.

(De Villiers, 1998: 40-44, 177-180).

\section{Verification of the foundation propositions}

The foundation propositions are submitted to the curriculum committee for further deliberations, amendments are recommended and the revised foundation propositions are accepted once the curriculum committee is satisfied with the amendments.

\section{Deliberations about the structure of the proposed curriculum}

This step is aimed at reaching consensus about the broad characteristics of the proposed curriculum. These characteristics are derived from the foundation propositions and findings of a situational analysis, and serve as a framework for the formulation of structure propositions.

\section{Conducting a situational analysis}

A situational analysis is undertaken to determine the social tendencies that influence the proposed curriculum. The purpose of the situational analysis is to ensure that the proposed curriculum is relevant to the society that the graduate will serve. The determinants of a curriculum, namely society, subject discipline and learner are investigated, and the results are documented in a situational analysis report.

\section{Formulating structure propositions}

Structure propositions refer to criteria for the proposed curriculum. These criteria are derived from the foundation propositions and the findings of the situational analysis. The structure propositions specify the intentions of the proposed curriculum and the required characteristics of each of the curriculum components. Criteria for the goals, content, learning opportunities and assessment of learning curriculum components are formulated. The structure propositions, together with the foundation propositions, serve as guidelines for designing a workable curriculum.

\section{Verification of the structure propositions}

The curriculum committee judges the extent to which the structure propositions are congruent with the foundation propositions and the findings of the situational analysis. Amendments are 
recommended and the structure propositions are accepted once the curriculum committee is satisfied with the revisions.

\section{Compiling a draft curriculum framework}

A draft curriculum framework, consisting of the foundation and structure propositions, is compiled and refined. There must be congruence between the foundation propositions, structure propositions and the findings of the situational analysis.

\section{Consulting with role players}

Consultation is the process by which the draft curriculum framework is submitted to the curriculum committee as well as to those stakeholders who have a vested interest in the proposed curriculum but who are not directly involved in curriculum development. The purpose is to involve these stakeholders in the curriculum development process by allowing them to give their inputs in the form of comments and recommendations. These comments and recommendations are incorporated in a consultation report. The curriculum planning cycle is then repeated to allow the curriculum committee to debate the consultation report and suggest further amendments to the draft curriculum framework.

The curriculum planning phase is concluded by adopting the draft curriculum framework. This serves as a broad guideline for the completion of the curriculum design phase.

\section{CURRICULUM DESIGN}

Curriculum design comprises a cycle of deliberations and verification that culminates in the adoption of a curriculum document. Various steps are followed to complete specified curriculum design tasks. The foundation and structure propositions that are included in the draft curriculum framework serve as guidelines for the completion of the curriculum design phase.

\section{Deliberations about an educational plan and an implementation strategy}

This step is aimed at designing an educational plan and an implementation strategy that will eventually be used in practice to guide teaching and learning.

\section{Designing an educational plan}

At this point the curriculum goal (aims, outcomes), curriculum content (subject matter, processes, skills), planned learning opportunities and assessment standards (intellectual and professional) are outlined and documented. The subject matter and learning opportunities are organised according to a distinct design. This constitutes an educational plan. The educational plan is then refined and will eventually be included in a curriculum document.

\section{Designing an implementation strategy}

This task involves the development of guidelines for the implementation of the educational plan. The implementation strategy is a description of the most desirable teaching-learning strategies, as well as guidelines aimed at proposing the nature of the role of the nurse educator and the learning climate. Strategies for the assessment of learning are also proposed in the form of assessment methods, criteria and rating scales for theoretical and clinical assessment. The purpose of the implementation strategy is to ensure that the aims and outcomes that are specified in the educational plan are achieved in practice.

Those responsible for designing the educational plan and those responsible for compiling the implementation strategy must work closely together to ensure that a meaningful and workable curriculum is developed. They should ensure that the educational plan and implementation strategy are consistent with each other and with the draft curriculum framework. 


\section{Verification of the educational plan and implementation strategy}

During this step, the educational plan and implementation strategy are scrutinised by the curriculum committee and amendments are proposed to rectify problem areas. The curriculum committee then oversees the refinement of the educational plan and the implementation strategy.

\section{Development of a curriculum document}

The revised educational plan and implementation strategy are submitted to the curriculum committee for evaluation and acceptance. A curriculum document is then compiled.

\section{Compiling a curriculum document}

A curriculum document consisting of the contents of the draft curriculum framework, the educational plan and the implementation strategy, is compiled. It is then prepared for submission to the curriculum committee for verification and final adoption.

\section{Verification of the curriculum document}

During this step the curriculum document is scrutinised by the curriculum committee. The curriculum committee ensures that there is congruence among the various components of the curriculum document, namely the foundation propositions, the structure propositions, the educational plan and the implementation strategy. The curriculum document should continue to be consistent with the latest social tendencies and ought to be acceptable to all the role players before it is finally adopted.

\section{Updating the situational analysis}

The situational analysis is updated to accommodate further social changes. The curriculum document is amended accordingly to ensure that the proposed curriculum is in line with the latest social, academic and professional tendencies.

\section{Consulting with role players}

The curriculum document is submitted to those role players that have provided inputs during the curriculum planning phase. The purpose is to enable them to familiarise themselves with the contents of the curriculum document and to suggest further changes. The curriculum document is then amended by incorporating the latest inputs of the role players. If required, some curriculum planning and design tasks are repeated in order to rectify problem areas.

The outcome of the curriculum design phase is the adoption of the curriculum document by the curriculum committee.

\section{CURRICULUM APPLICATION}

The application phase comprises curriculum implementation and curriculum evaluation.

\section{Curriculum implementation}

Curriculum implementation is an essential part of curriculum development because it is through implementation that the intended changes, as specified in the curriculum document, are applied in practice (Ornstein \& Hunkins 1998:291-292). The implementation strategy could serve as a point of reference for developing a personnel development programme. The members of the curriculum committee act as consultants who advise educators on the implementation of the curriculum. They also provide inputs during personnel development sessions about the demands of the new curriculum.

\section{Implementing the educational plan}

The educational plan is implemented in practice according to the guidelines that are included in the implementation strategy. Limitations are recorded and the educational plan is amended to rectify 
problem areas.

\section{Curriculum evaluation}

The newly developed curriculum is implemented for a specified period of time, after which curriculum evaluation is done to evaluate the extent to which curriculum development and implementation succeeded in achieving the intended results (Billings \& Halstead 1998:179205). The curriculum committee is responsible for developing a curriculum evaluation strategy.

\section{Compiling a curriculum evaluation document}

Curriculum evaluation occurs by means of a planned curriculum evaluation project. The foundation and structure propositions serve as evaluation criteria. Furthermore, these foundation and structure propositions are evaluated for its relevance in the light of continued social change and changing tendencies in health care, education and the nursing profession.

The curriculum evaluation results are documented and included in a curriculum evaluation document. This document serves as a stimulus and a point of departure for a repetition of the curriculum development process by reactivating the curriculum planning phase.

\section{CONCLUSION}

A process curriculum development model was discussed. Curriculum development is a process that consists of three phases namely curriculum planning, design and application. Each of these phases consists of steps aimed at performing designated curriculum development tasks. The Model for Curriculum Development in Nursing contributes towards a comprehensive curriculum development approach that could result in fundamental curriculum changes.

\section{REFERENCES}

Billings, DM \& Halstead, JA 1998: Teaching in nursing. A guide for faculty. Philadelphia: WB Saunders.

Brown, L (Editor) 1993: The new shorter Oxford English dictionary on historical principles. Volume 1. Oxford: Claredon Press.

De Villiers, L 1998: 'n Model vir kurrikulum ontwikkeling in verpleegkunde. Universiteit van SuidAfrika (D. Litt. et Phil. tesis).

De Villiers, L 1999 A study for the development of a curriculum development model for nursing education.

Health SA Gesondheid, 4(3):3-11.

George, JB 1995: Nursing theories. The base for professional nursing practice; $4^{\text {th }}$ edition. London: Prentice-Hall.

Gravett, S \& Henning, E 1998: Teaching as dialogic mediation: A learning centred view of higher education.

SA Journal for Higher Education, 12(2):60-68.

Grundy, S 1987: Curriculum: Product or praxis. Philadelphia: Falmer Press.

Klein, MF 1986: Alternative curriculum conceptions and designs, Theory into Practice, XXV(i):31-35.

Lawton, D 1983: Curriculum studies and educational planning. London: Hodder \& Stroughton.

Lefrancois, GR 1997: Psychology for teaching; ninth edition. London: Wadsworth Publishing Company.

Lovat, TJ \& Smith, DL 1995: Curriculum: Action on reflection revisited; $3^{\text {rd }}$ edition. Wentworth Falls: Social Science Press.

McNeil, JD 1996: Curriculum. A comprehensive introduction; $5^{\text {th }}$ edition. Los Angeles: Harper Collins. 
Nicholls, A \& Nicholls, SH 1978: Developing a curriculum: A practical guide. London: George Allen \& Unwin.

Ornstein, AC \& Hunkins, F 1998: Curriculum: Foundations, principles and issues; third edition. Boston: Allyn \& Bacon.

Ornstein, AC \& Levine, DU 1993: Foundations of education; fifth edition. Boston: Houghton Mifflin.

Print, M 1993 Curriculum development and design; second edition. St. Leonards: Allen Unwin.

Short, EC \& Grove, RW 1994: Conceptual schemes in curriculum inquiry and practice: A critique. Curriculum and Teaching, 9(1):3-12.

South African Nursing Council, 1985: Regulations leading to approval and the minimum requirements for the education and training of a nurse (general, psychiatric and community) and midwife leading to registration. $\mathrm{R}$. 425. (As amended). Pretoria: State Printer.

Spady, WG \& Marshall, KJ 1991: Beyond traditional outcome-based education. Educational Leadership, October 1991:67-72.

Stucky, C 1997: Scant policy direction as colleges change curricula. The Sunday Independent, 27 July 1997:9.

Tanner, D \& Tanner, L 1995: Curriculum development: Theory into practice. New Jersey: Englewood Cliffs.

Vallance, E 1986: A second look at conflicting conceptions of curriculum. Theory into Practice, XXV(1):24-30.

Walker, DF 1971: A naturalistic model for curriculum development. School Review, November 1971:51-64.

Walker, DF \& Soltis, JF 1992: Curriculum and aims; second edition. New York: Teachers College Press.
Zais, RS 1976: Curriculum principles and foundations. New York: Harper \& Row. 